\title{
PENYALAHGUNAAN KEADAAN (MISBRUIK VAN OMSTANDIGHEDEN) SEBAGAI LARANGAN DALAM PERJANJIAN SYARIAH
}

\author{
Dwi Fidhayanti \\ Fakultas Syariah Universitas Islam Negeri Maulana Malik Ibrahim Malang \\ Email: $\underline{\text { fidha.shi@gmail.com }}$
}

\section{Abstracts}

The principle of freedom of contract may cause problems in the form of an indication of misuse of circumstances (misbruik van omstandigheden) in the agreement. Misuse of circumstances (misbruik van omstandigheden) occurs when a person in a covenant is influenced by something that prevents him from making a judgment free from the other so that he can not take an independent decision. This research uses normative research with a legislative approach. Invitations and conceptual approaches. Legal material is obtained through literature study and analyzed by legal interpretation method. The results of the study and discussion show that the concept of misuse of state (misbruik van omstandigheden) in the agreement is included in a covenant with a defective will. One party who has a strong position to suppress and even threaten against parties who have a weaker position so Bargaining position is not balanced. Persons who have a weak position are not given the freedom to give their opinion on the contents of the agreement. Sharia treaties that contain elements of abuse of the circumstances (misbruik van omstandigheiden or undue influence) are included in the forbidden agreement, called ikrah. To do slander is to do wrongdoing. As a result of the law, the agreement becomes null and void.

Asas kebebasan berkontrak dapat menimbulkan permasalahan berupa adanya indikasipenyalahgunaan keadaan (misbruik van omstandigheden) dalam perjanjian. Penyalahgunaan keadaan (misbruik van omstandigheden) terjadi manakala seseorang di dalam suatu perjanjian dipengarubi oleh suatu halyangmenghalanginya untuk melakukan penilaian (judgement) yang bebas dari pihak lainnya, sehingga ia tidak dapat mengambil putusan yang independen. Penelitian ini menggunakan penelitian normatif dengan pendekatan perUndang-Undangan dan pendekatan 
konseptual. Bahan hukum didapatkan melalui studipustaka dan dianalisis dengan metode intepretasi hukum. Hasilpenelitian dan pembahasan menunjukkan bahwa konsep penyalahgunaan keadaan (misbruik van omstandigheden) dalam perjanjian termasuk dalam perjanjian yang cacat kehendak. Salah satu pihak yang mempunyai posisi kuat untuk menekan bahkan mengancam terhadap pibak yang mempunyai posisi lebih lemah sehingga Bargaining position tidak seimbang. Pihak yang punya posisi lemah tidak diberikan kebebasan untuk memberikan pendapatnya atas isi perjanjian. Perjanjian syariah yang mengandung unsur penyalahgunaan keadaan (misbruik van omstandigheiden atau undue influence) termasuk pada perjanjian yang dilarang, yang disebut dengan ikrah. Berbuat Ikrah berarti berbuat zalim. Akibat hukumnya, yaitu perjanjian tersebut menjadi batal demi hukum.

Keywords: misuse of state, misbruik van omstandigheden, probibition in sharia agreement

\section{Pendahuluan}

Perjanjian merupakan salah satu cara untuk memperoleh sesuatu yang banyak digunakan dalam kehidupan sehari-hari, khususnya dalam melakukan kegiatan ekonomi. Perjanjian ini harus dibuat oleh kedua belah pihak yang bertransaksi dan dari perjanjian ini lah yang menentukan sah atau tidaknya suatu transaksi. Hukum perjanjian syariah merupakan aspek yang memegang peranan penting di dalam pelaksanaan muamalah.

Perjanjian dalam Hukum Islam disebut dengan perjanjian syariah atau Akad, yaitu perjanjian antara kedua belah pihak yang bertujuan untuk saling mengikatkan diri tentang perbuatan yang akan dilakukan dalam suatu hal, yang diwujudkan dalam ijab (penawaran) dan qabul (penerimaan) yang menunjukkan adanya kerelaan secara timbal balik antara kedua belah pihak dan harus sesuai dengan kehendak syariat. Dengan demikian, Hukum Perjanjian syariah pada prinsipnya juga menganut asas kebebasan berkontrak yang dituangkan dalam antaradhin sebagaimana diatur dalam QS. An-Nissa ayat 29:

"Hai orang-orangyang beriman, janganlah kamu saling memakan harta sesamamu dengan jalan yang batil, kecuali dengan jalan perniagaan yang Berlaku dengan suka sama-suka di antara kamu.dan janganlah kamu membunub dirimu; Sesunggubnya Allah adalah Maha Penyayang kepadamu."

Terdapat Hadits Nabi Muhammad SAW tentang asas kebebasan berkontrak yang dituangkan dalam antaradhin sebagaimana diriwayatkan oleh Baihaqi, Ibn Hibban dan Ibn Majjah bahwa: 
"Dari Abu Said al-Hudriyyi bahwa Rasulullah SAW bersabda: sesunggubnya jual beli itu harus dilakukan secara suka sama suka." (Hadits diriwayatkan oleh Baibaqi, Ibnu Majah, dan shabih menurut Ibnu Hibban) ${ }^{1}$

Dalam perkembangannya, asas kebebasan berkontrak dapat menimbulkan permasalahan berupa adanya indikasi penyalahgunaan keadaan (misbruik van omstandigheden) dalam perjanjian.Penyalahgunaan keadaan (misbruik van omstandigheden) terjadi manakala seseorang di dalam suatu perjanjian dipengaruhi oleh suatu hal yang menghalanginya untuk melakukan penilaian (judgement) yang bebas dari pihak lainnya, sehingga ia tidak dapat mengambil putusan yang independen. ${ }^{2}$ Penekanan tersebut dapat dilakukan karena salah satu pihak dalam perjanjian memiliki kedudukan lebih tinggi, sedangkan pihak yanglain mempunyai kedudukan yang lebih rendah. Pihak yang memiliki kedudukan lebih tinggi itu mengambil keuntungan secara tidak pantas dari pihak lainnya yang lebih rendah. Penyalahgunaan keadaan (misbruik van omstandigheden) yang demikian lebih mengarah kepada penyalahgunaan dalam hal keunggulan ekonomis maupun kejiwaan.

Penyalahgunaan keadaan secara ekonomis seringkali ditemui dalam perjanjanjian-perjanjian bisnis, tidak terkecuali dalam bisnis berbasis syariah yang menggunakan perjanjian syariah. Penyalahgunaan keadaan menyebabkan ketidakseimbangan antara para pihak dalam perjanjian. Penyalahgunaan keadaan belum diatur secara jelas dalam Kitab Undang-Undang Hukum Perdata maupun peraturan perUndang-Undangan lainnya.Berdasarkan hal tersebut, peneliti berusaha mengkaji konsep penyalahgunaan keadaan (misbruik van omstandigheden) dalam perjanjian. Setelah itu, hasilnya akan dianalisis untuk dapat mengetahui Apakah konsep penyalahgunaan keadaan (misbruik van omstandigheden) dapat dikategorikan sebagai larangan dalam perjanjian syariah.

\section{Metode Penelitian}

Penelitian ini adalah penelitian normatif dengan pendekatan perUndangUndangan (statue approach) dan pendekatan konsep (conceptual approach). Perjanjian pembiayaan pada beberapa bank syariah ditelaah untuk mengetahui

1 Abu Hatim Muhammad ibn Hibban al-Tamimi al-Darimi al-Busti, Shahih Ibn Hibban, (Beirut: Mu'assasah ar- Raisalah,1414/1993), hlm. 340, hadits no. 4967; dan Abu Abdullah Muhammad bin Yazid bin Abdullah bin Majah Al Quzwaini, Sunan Ibn Majah, (Beirut: Dar al-Fikr, 1993), h. 737, hadits no. 2185.

2 Ridwan Khairandy, Kemerosotan Supremasi Asas Kebebasan Berkontrak. Makalah disampaikan pada Departermen Hukum Keperdataan Fakultas Hukum Universitas Islam Indonesia Yogyakarta pada tanggal 16 Agustus 2000, h.8-9. 
bentuk penyalahgunaan secara ekonomi. Kemudian beberapa peraturan seperti Undang-Undang Perlindungan Konsumen, Undang-Undang No.10 Tahun 1998 tentang Perbankan dan Undang-Undang No. 21 Tahun 2008 tentang Perbankan syariah, Kitab Undang-Undang Hukum Perdata. Tulisan ini juga mempelajari beberapa konsep hukum berkaitan dengan konsep penyalahgunaan keadaan (misbruik van omstandigheden) menurut Hukum Islam. Bahan hukum primer, bahan hukum sekunder dan bahan hukum tersier dikumpulkan dengan menggunakan studi pustaka. Bahan hukum di analisis menggunakan penafsiran hukum berupa intepretasi secara sistematis dan intepretasi secara ekstensif.

\section{Pembahasan}

Konsep Penyalahgunaan Keadaan (Misbruik Van Omstandigheden) dalam Perjanjian

Berkembanganya ekonomi masyarakat ke arah yang lebih modern membuat masyarakat memiliki kebutuhan yang semakin banyak. Masyarakat perlu untuk berusaha agar kebutuhannya dapat terpenuhi. Dalam memenuhi kebutuhannya hidup, sesama anggota masyarakat saling membutuhkan satu sama lain. Hubungan antara masyarakat yang satu dengan masyarakat yang lain diikat dalam suatu perjanjian hingga melahirkan seperangkat hak dan kewajiban.

Pasal 1313 BW memberikan rumusan tentang perjanjian bahwa "suatu perjanjian adalah suatu perbuatan dengan mana satu orang atau lebih mengikatkan dirinya terhadap satu orang lain atau lebih". Perjanjian mengatur para pihak yang mengikatkan dirinya terhadap satu orang lain atau lebih. Perjanjian mengandung suatu prestasi yang diperjanjikan. Kreditur berhak atas prestasi yang diperjanjikan dan debitur wajib melaksanakan prestasi tersebut. Maka, objek dari perjanjian adalah prestasi itu sendiri. Para pihak menentukan prestasinya dalam hak dan kewajiban mereka yang tertulus dalam klausul-klausulnya, yaitu aturan tentang bagaimana para pihak menjalani hubungan hukum mereka untuk mencapai visi misi bersama.

Para pihak dapat menciptakan perjanjian-perjanjian baru baik yang dikenal dalam hukum perjanjian bernama dan yang isinya dapat pula menyimpang dari perjanjian bernama yang diatur oleh Undang-Undang. ${ }^{3} \mathrm{Hal}$ ini mengacu pada asas kebebasan berkontrak (freedom of contract). Asas kebebasan berkontrak tercermin dari ketentuan pasal 1338 ayat (1) KUH Perdata, yang menyatakan bahwa semua kontrak (perjanjian) yang dibuat secara sah berlaku sebagai Undang-Undang bagi mereka yang membuatnya.

3 J.Satrio, Hukum Perikatan, Perikatan pada Umumnya (Bandung: Alumni, 1999), h.36. 
Pasal 1338 ayat 1 KUH Perdata secara tegas menetapkan suatu perjanjian mempunyai daya kekuatan mengikat sebagai Undang-Undang, bahkan berlaku sebagai lex specialis terhadap ketentuan umum yang berlaku dan mengikat para pihak yang menandatangani kontrak tersebut. ${ }^{4}$ Pasal 1338 ayat $1 \mathrm{KUH}$ Perdata juga menujukkan bahwa hukum perjanjian menganut sistem terbuka (opened system), yaitu memberi kebebasan seluas-luasnya kepada masyarakat untuk mengadakan perjanjian yang berisi apa saja, sepanjang tidak melanggar UndangUndang,kesusilaan dan ketertiban umum. ${ }^{5}$ Perjanjian juga harus mengacu pada syarat suatu perjanjian yang diatur dalam pasal $1320 \mathrm{KUH}$ Perdata tentang syarat sah perjanjian.

Kesepakatan dalam menentukan dan membuat suatu perjanjian merupakan kesepakatan yang saling mengutungkan (mutual benefit). Namun, pembuatan perjanjian senantiasa bertolak belakang dari sikap win-win attitude, yaitu suatu sikap yang dilandasi oleh itikad baik, bahwa kontrak itu sedapat mungkin akan menguntungkan secara timbal balik. Itulah sebabnya, pangkal tolak dari setiap perjanjian sebenarnya adalah itikad baik, sekalipun dalam penyusunannya boleh saja melibatkan taktik dan strategi. ${ }^{6}$

Taktik dan strategi seringkali digunakan oleh pihak yang berada dalam posisi ekonomi kuat untuk berusaha merebut dominasi atas pihak lainnya dan saling berhadapan sebagai lawan kontrak. Pihak yang posisinya lebih kuat dapat memaksakan keinginannya terhadap pihak lain demi keuntungannya sendiri, sehingga melahirkan isi dan syarat kontrak yang berat sebelah atau tidak adil. Ketidak adilan tersebut timbul karena adanya kebebasan para pihak tidak dapat dimaknai sebagai kehendak sepihak, akan tetapi kehendak dua belah pihak atau berbagai pihak.

Perjanjian membutuhkan adanya keseimbangan antara para pihak. Pengertian "keseimbangan-seimbang" atau "evenwitchevenwichtig" (Belanda) atau "equalityequal-equilibrium" (Inggris) bermakna leksikal "sama, sebanding” menunjuk pada suatu keadaan, posisi, derajat, berat, dan lain-lain. Keseimbangan berkontrak pada hubungan antara bank-nasabah, menyimpulkan bahwa keseimbangan para pihak hanya akan terwujud apabila berada pada posisi yang sama kuat. ${ }^{7}$ Sutan Remi Sjahdeini memahami keseimbangan para pihak yang melakukan perjanjian dari

4 Ricardo Simanjuntak, "Akibat Dan Tindakan-Tindakan Hukum Terhadap Pencantuman Klausula Baku Dalam Polis Asuransi Yang Bertentangan Dengan Pasal 18 Undang-Undang No.8/1999 Tentang Perlindungan Konsumen", Jurnal Hukum Bisnis, Vol. 22, No. 2, Tahun 2003, h. 56.

5 Subekti, Aneka Perjanjian (Bandung: Citra Aditya Bakti, 1995), h.3.

6 Agus Yudha Hernoko, Hukum Perjanjian Asas Proposionalitas Dalam Kontrak Komersial (Surabaya: Kencana Prenada Media Grup, 2013), h. 39.

7 Agus Yudha Hernoko, Hukum Perjanjian Asas Proposionalitas Dalam Kontrak Komersial, h. 27. 
posisi atau kedudukan para pihak yang (seharusnya) sama. Seringkali kesepakatan merupakan adanya kekeliruan (dwaling), penipuan (bedrog) atau paksaan (dwang). Kesepakatan memang terjadi, tetapi di dalam kesepakatan kerapkali mengandung unsur penipuan atau paksaan.

Ancaman/ Paksaan (Bedreiging, Dwang). Diatur dalam pasal $1324 \mathrm{KUH}$ Perdata. Paksaan merupakan kekerasan jasmani atau ancaman memengaruhi kejiwaan yang menimbulkan ketakutan pada orang lain sehingga dengan sangat terpaksa membuat suatu perjanjian. Paksaan dapat berupa paksaan mutlak (absolut) dan paksaan relatif. Paksaan Mutlak artinya subjek perjanjian dalam hal ini ditempatkan dalam posisi tidak ada pilihan lain, atau ditempatkan pada posisi harus menerima perjanjian tersebut. Sementara Paksaan relative masih memberikan kesempatan bagi salah satu yang dipaksa untuk mempertimbangkan menerima atau menolak perjanjian tersebut. Suatu ancaman dapat terjadi atau dilakukan dengan menggunakan cara atau sarana yang legal maupun ilegal. Contoh sarana yang legal adalah mengancam dengan menggunakan pisau. Sedangkan, contoh sarana yang legal adalah mengancam untuk melakukan permohonan pailit.

Kekeliruan/kesesatan/kekhilafan (dwaling). Pasal 1322 KUHPer membedakan kesesaatan atau kekhilafan menjadi dua jenis, yakni error in personal dan error in substantia. Yang dimaksud dengan error in personal adalah kekhilafan mengenai hakikat orangnya. Dalam kondisi ini pembatalan perjanjian dilakukan atas dasar permintaan dari pihak yang dirugikan. Sementara error in substantia merupakan kondisi khilaf atau sesat mengenai hakikat barangnya.

Penipuan (bedrog). Penipuan terjadi apabila seseorang secara sengaja dengan kehendak dan pengetahun menimbulkan kesesatan pada orang lain. Perbuatan yang dikategorikan sebagai penipuan misalnya fakta yang dengan sengaja disembunyikan atau apabila ada informasi maka informasi tersebut sengaja diberikan secara keliru atau dengan menggunakan tipu daya lainnya. Pihak yang merasa dirugikan harus dapat membuktikan adanya penipuan.

Kesepakatan yang mengandung unsur kekeliruan (dwaling), penipuan (bedrog) atau paksaan (dwang) termasuk kesepakatan yang cacat kehendak. Cacat kehendak (wilsgebreken atau defect af consent) adalah kecacatan dalam pembentukan kata sepakat dalam suatu kontrak atau perjanjian perjanjian tersebut menjadi tidak sempurnanya kata sepakat. Kesepakatan yang mengandung cacat kehendak tampak adanya kata sepakat, tetapi kata sepakat itu dibentuk tidak berdasar kehendak bebas. Maksudnya salah satu pihak dalam memberikan kesepakatan merasa terbatasi oleh suatu hal.

Pasal 1321 KUHPerdata menyebutkan geene toesteming is van waarde, 
indien dezelve door dwaling is gegeven, door geweld algeperst, af door bedrog verlvegen (tiada kesepakatan yang memiliki kekuatan jika diberikan karena kekhilafan, atau diperolehnya karena paksaan atau penipuan). ${ }^{8}$ Cacat kehendak yang tercantum dalam pasal $1321 \mathrm{KUH}$ perdata dinamakan cacat kehendak yang klasik.Selain cacat kehendak yang dimaksud Pasal 1321 KUHPerdata tersebut, di dalam praktik peradilan yang tercermin dari yurisprudensi dikenal pula bentuk cacat kehendak yang keempat, yakni penyalahgunaan keadaan (misbruik van omstandigheiden atau undue influence). Dalam sistem common law, selain undueinfluence dikenal pula unconscionability, yang keduanya berbeda, meskipun memiliki kesamaan yakni keduanya didasarkan pada adanya ketidakseimbangan posisi tawar para pihak. ${ }^{9}$ Cacat kehendak yang terjadi akibat penyalahgunaan keadaan (undue influence) belum banyak diulas dalam beberapa literature.

Lembaga hukum (Rechstffguur) penyalahgunaan keadaan (Misbruik Van Omstandigheiden atau Undue Influence) merupakan bentuk cacat kehendak yang baru dalam sistem hukum kontrak Belanda.Hukum kontrak Belanda mengadopsi lembaga penyalahgunaan keadaan ini dari hukum Inggris. ${ }^{10}$ Negara-negara dengan sistem common law sudah lama menerima doktrin Penyalahgunaan Keadaan (misbruik van omstandigheiden). Belanda mencantumkan suatu ajaran baru yaitu Misbruik van Omstandigheden (penyalahgunaan keadaan). Di dalam ketentuan Undangundang Belanda, khususnya dalam Nieuw Burgerlijk Wetboek (selanjutnya disebut NBW), penyalahgunaan keadaan ini di atur dalam artikel 3:44 lid 1 NBW.

Doktrin Penyalahgunaan Keadaan (misbruik van omstandigheiden) dikenal dengan doktrin equality.doktrinequality berkembang pada abad 19 (sembilan belas) yang merupakan bagian dari perluasan power of equity bagi pengadilan untuk mengintervensi suatu perjanjian yang di dalamnya terdapat suatu penyalahgunaan posisi yang tidak seimbang diantara para pihak. Hubungan para pihak yang tidak seimbang ini dinamakan Undue Influence. Seseorang di dalam suatu perjanjian dipengaruhi oleh suatu hal yang menghalanginya untuk melakukan penilaian (judgment) yang bebas dari pihak lainnya, sehingga ia tidak dapat mengambil putusan yang independen.

Apabila merujuk pada pasal 3: 44 (4) NBW, terdapat beberapa keadaan yang dapat digolongkan ke dalam penyalahgunaan keadaan, yaitu: noodtoestand (keadaan darurat); afhankelijkheid (ketergantungan); lichtzinnigheid (gegabah/

8 Yenny Triana, Pemahaman Iktikad Baik Dan Penyalahgunaan Keadaan Dalam Kontrak, Fakultas Hukum Universitas Lancang Kuning, h. 2.

9 Muhammad Arifin, Penyalahgunaan Keadaan Sebagai Faktor Pembatas Kebebasan Berkontrak, Jurnal Ilmu Hukum, Vol. 14, No. 2, September 2011, h. 284.

10 Ridwan Khairandy, Hukum Kontrak Indonesia Dalam Perspektif Perbandingan (Bagian Pertama) (Yogyakarta: FH UII Press, 2013), h. 227. 
sembrono); abnormale geestestoestand (keadaan kejiwaan yang tidak normal); dan onervarenheid (kurang pengalaman). ${ }^{11}$ Secara umum Penyalahgunaan keadaan dibagi dalam dua kelompok yaitu:

1. Penyalahgunaan kedaan karena keunggulan ekonomi (economischeoverwicht) dari satu pihak terhadap pihak lain;

2. Penyalahgunaan keadaan karena keunggulan psikologis (geestelijkeoverwicht) dari satu pihak terhadap pihak lain.

Van Dunne membagi penyalahgunaan keadaan menjadi tiga bagian, yaitu: penyalahgunaan keunggulan ekonomis; ${ }^{12}$ penyalahgunaan keunggulan kejiwaan; dan penyelahgunaan keadaan darurat. Penyalahgunaan keadaan darurat memiliki arti yang luas. Keadaan darurat tidak hanya meliputi keadaan yang mengancam kesehatan, jiwa, kehormatan, atau kebebasan, melainkan juga kerugian yang mengancam milik maupun reputasi pribadi dan/atau kebendaan. Misalnya sikap tindak untuk memperoleh keuntungan tertentu dengan memanfaatkan keadaan bahaya atau keadaan lemah dari pihak lain. Namun, pada dasarnya, penyalahgunaan keadaan darurat ini digolongkan kedalam kategori penyalahgunaan keunggulan ekonomis.

Contoh klausul yang mengandung Penyalahgunaan Keadaan (misbruik van omstandigheiden) dalam sebuat perjanjian pembiayaan bank seperti:

Nasabah bersedia menanggung semua biaya yang berkenaan dengan pelaksanaan Perjanjian, termasuk tetapi tidak terbatas pada biaya Notaris dan jasa lainnya.

Apabila penjualan barang jaminan dilakukan dibawah tangan maka Nasabah dan Bank sepakat, harga penjualan barang jaminan ditetapkan oleh Bank dengan harga yang wajar menurut harga pasar ketika barang jaminan dijual.

Nasabah bertanggung jawab untuk memeriksa dan meneliti kondisi Barang yang dibeli dari Pemasok, termasuk terhadap sahnya dokumen-dokumen atau surat-surat bukti kepemilikan Barang. Bank tidak berkewajiban memeriksa kondisi Barang dan tidak bertanggung jawab atas cacat-cacat tersembunyi atas Barang serta tidak bertanggung jawab atas ketidak absahan dokumen kepemilikan Barang.

Kata yang digunakan dalam contoh-contoh klausul di atas menunjukkan bahwa Bank sebagai pihak yang mempunyai posisi ekonomi kuat mendominasi isi dari perjanjian dengan cara melimpahkan yang seharusnya tanggung jawab bersama menjadi tanggung jawab sepihak bagi nasabah saja dan bahkan Bank

11 Herlien Budiono, Ajaran Umum Hukum Perjanjian Dan Penerapannya Di Bidang Kenotariatan (Jakarta: Citra Aditya Bakti, 2010), h. 98.

12 Fatmah Paparang, "Misbruik Van Omstandigheden Dalam Perkembangan Hukum Kontrak", Jurnal Hukum Unsrat Vol. 22 No.6 Juli 2016, h. 51. 
tidak mau menerima risiko apapun yang timbul dari perjanjian.

Contoh klausul perjanjian di atas merupakan salah satu bentuk penyalahgunaan keadaan yang dikategorikan sebagai penyalahgunaan keadaan secara ekonomi. Penyalahgunaan keadaan ekonomi menyebabkan kerugian yang jelas dan konkret yang dialami salah satu pihak. Penyalahgunaan keadaan secara ekonomi dapat ditentukan dengan menjawab beberapa pertanyaan seputar unsur-unsur penyalahgunaan secara ekonomi sebagai berikut:

1. Apakah ada keunggulan ekonomis? Ya, Nasabah yang menginginkan suatu prestasi tertentu yang sangat dibutuhkannya harus menerima klausul dalam perjanjian meskipun dapat merugikan dirinya. Penyebabnya adalah bargaining position-nya lebih rendah daripada pihak lawannya. Nasabah yang membutuhkan dana tetap harus membiayai semua biaya yang timbul dari perjanjian, meskipun hubungan antara Bank dan Nasabah ini bersifat simbiosis mutualisme atau hubungan timbal balik yang saling menguntungkan.

2. Adakah kebutuhan mendesak untuk mengadakan perjanjian dengan pihak yang mempunyai ekonomi lebih kuat? Contoh klausul perjanjian pembiayaan di atas makna orang yang membutuhkan pembiayaan membutuhkan dana untuk keperluan investasi dan sebagian besar menggunakan kredit / pinjaman untuk keperluan konsumsi.

3. Apakah perjanjian yang telah dibuat/ telah disetujui itu tidak berimbang dan menguntungkan pihak yang mempunyai ekonomi lebih kuat? Ya, karena nasabah yang mengajukan pembiayaan akan dikenakan biaya administrasi, kemudian nisbah untuk Bank juga tinggi hampir mencapai 100\% dari nilai pembiayaan.

4. Apakah keadaan berat sebelah dapat dibenarkan oleh keadaan istimewa? Tidak. Keadaan-keadaan istimewa (bijzondere onstandigheden), seperti keadaan darurat, ketergantungan, ceroboh, jiwa yang kurang waras dan tidak berpengalaman. Apabila seseorang dalam ketergantungan, ceroboh dan jiwa yang kurang waras termasuk orang yang harus berada dibawah pengampuan sehingga orang tersebut tidak dapat melakukan suatu perbuatan hukum seperti membuat perjanjian.

Apabila unsur-unsur tersebut terpenuhi, maka perjanjian pembiayaan Bank syariah sebagaimana contoh di atas mengandung penyalahgunaan keadaan secara ekonomis.Perjanjian yang mengandung penyalahgunaan keadaan dikategorikan sebagai perjanjian yang cacat kehendak sehingga menimbulkan akibat hukum perjanjian dapat dibatalkan (vernietigbaar). Pembatalannya dimintakan kepada hakim oleh pihak yang dirugikan dengan cara membuktikan adanya ketidakseimbangan prestasi yang mencolok antara bank dan nasabah karena adanya tekanan keadaan, 
yang oleh pihak yang mempunyai ekonomi kuat disalahgunakan dengan akibat pihak lawan janjinya tidak dapat menyatakan kehendaknya secara bebas. Sepanjang perjanjian belum dibatalkan, maka perjanjian tetap mengikat para pihak yang membuatnya.

Hingga saat ini belum terdapat peraturan perUndang-Undangan di Indonesia yang secara limitatif menyebutkan kriteria penyalahgunaan keadaan. Setiap kasus yang terjadi harus dilihat secara obyektif-rasional mengenai situasi dan kondisi pada saat ditutupnya perjanjian dan formulasi prestasi maupun kontra prestasi pada penjanjian itu sendiri.

\section{Konsep Penyalahgunaan Keadaan (Misbruik Van Omstandigheden) Sebagai Larangan Dalam Perjanjian Syariah}

Transaksi merupakan suatu kegiatan yang dilakukan seseorang yang mengakibatkan adanya perubahan terhadap harta atau keuangan yang dimiliki baik itu bertambah ataupun berkurang. Kegiatan tersebut dapat berupa menjual harta, membeli barang, membayar hutang, serta membayar berbagai macam biaya untuk memenuhi kebutuhan hidup. Transaksi dalam sistem ekonomi yang berparadigma Islam senantiasa harus dilandasi oleh aturan hukum-hukum islam (syariab), karena transaksi adalah manifestasi amal manusia yang mempunyai nilai ibadah dihadapan Allh SWT. transaksi dapat dikelompokkan menjadi dua, yaitu: Transaksi yang halal. Transaksi yang haram. Transaksi halal adalah semua transaksi yang diperbolehkan oleh syariat islam, sedangkan transaksi yang haram adalah kebalikannya yaitu dilarang oleh syariat islam.

"pada asasnya segala sesuatu itu boleh dilakukan sampai ada dalil yang melarangnya".

Bahwa segala sesuatu itu sah atau boleh dilakukan apabila tidak ada larangan yang secara tegas tidak memperbolehkan tindakan tersebut. Apabila dikaitkan dengan transaksi, maka hal ini berarti bahwa tindakan hukum dan transaksi apapun dapat dibuat sejauh tidak ada larangan khusus mengenai perjanjian tersebut.

Transaksi antara satu orang dengan orang lainnya berdasarkan asas al-kitabah harus dibuat secara tertulis. Transaksi yang dibuat dengan cara tertulis bertujuan untuk membudahkan dalam pembuktian, acuan bekerja sama dan melaksanakan transaksi. Kesepakatan dalam transaksi dituangkan dalam sebuah perjanjian.

Perjanjian syariah dalam Hukum Islam dikenal dengan istilah akad. Akad dalam bahasa arab disebut dengan al-aqdu. Secara bahasa akad dapat diartikan 
dengan ikatan atau mengikat. ${ }^{13}$ Para ahli hukum islam atau jumhur ulama mendefinisikan akad sebagai pertalian antara ijab dan qabul yang dibenarkan oleh syarak yang menimbulkan akibat hukum terhadap objeknya. Akibat hukum ini yang menjadi tujuan dari diadakannya akad sebagai maksud bersama yang akan dituju dan yang hendak diwujudkan oleh para pihak dalam suatu akad.

Ulama fiqih menetapkan bahwa perjanjian yang telah memenuhi rukun dan syaratnya mempunyai kekuatan mengikat terhadap pihak-pihak yang melakukannya. Maksud dari kekuatan mengikat dalam perjanjian adalah bahwa perjanjian hanya mengikat bagi para pihak yang mengikatkan diri pada perjanjian tersebut dan sifatnya hanya mengikat ke dalam. Para pihak harus tunduk dan patuh pada ketentuan perjanjian yang mereka buat sebagaimana tunduk dan patuh kepada Undang-Undang.

Sesuai dengan ketentuan pasal 2 ayat (3) PBI No.10 / 16/PBI/2008 tentang pelaksanaan Prinsip Syariah dalam kegiatan Penghimpunan Dana dan Penyaluran Dana serta Pelayanan Jasa Bank Syariah, pemenuhan prinsip syariah dilaksanakan dengan memenuhi ketentuan pokok hukum Islam. Prinsip syariah yang mempunyai dampak yang signifikan terhadap suatu akad, yaitu keadilan dan keseimbangan ('Adl wa Tawazun). Gemala Dewi menyebutnya sebagai Asas persamaan atau kesetaraan (mabda'at-ta'awazun fial-mu'awadhah), yaitu pada keseimbangan dari hak dan kewajiban bagi para pihak yang dituangkan dalam bentuk akad. Selain itu, kesetaraan dalam hal memikul risiko juga harus diperhatikan pada perjanjian yang berdasarkan prinsip syariah ini.

Keseimbangan, persamaan atau kesetaraan Hak dan kewajiban akan tercapai apabila para pihak saling bersepakat atas isi dari perjanjian yang akan dilakukan. Kesepakatan yang seimbang dapat menyeimbangkan kedudukan para pihak. Para pihak tidak saling menekan satu sama lain dengan adanya bargaining position yang seimbang.

Dunia bisnis perbankan dituntut untuk pemenuhan target keuntungan dan menjaga uang nasabah penabung yang mempunyai kelebihan dana dengan cara hati-hati seringkali membuat bank mensalah gunakan kedudukannya. Bank sebagai pihak yang menyalurkan kelebihan dana milik nasabah penabung menggunakan efisiensi sebagai alasan. Efisiensi tersebut diterapkan pada perjanjian atau akad para pihak dengan cara membuat perjanjian tersebut dibuat secara formulir atau dikenal dengan peranjian baku. Perjanjian atau akad dibuat dalam bentuk tertulis yang semua isinya sudah ditentukan oleh bank. Nasabah tidak mempunyai kesempatan untuk menegosiasikan isi dari perjanjian dan akad tersebut. Nasabah

13 Gemala Dewi, Dkk, Hukum Perikatan Islam di Indonesia, cet. Ke-2 (Jakarta: Kencana, 2006), h. 45. 
hanya mempunyai pihilan take it or leave it.

Situasi yang demikian rawan atas terjadinya penyalahgunaan keadaan oleh si pemilik posisi kuat, yaitu bank. Bargaining position para pihak dalam perjanjian menjadi berat sebelah. Nasabah yang tidak mempunyai pilihan dengan cara terpaksa menandatangani isi perjanjian meskipun isinya memberatkan nasabah. Nasabah yang membutuh dana tidak mempunyai kesempatan untuk memberikan pendapatnya karena semua ketentuan dan persyaratan sudah ditentukan oleh bank.

Islam tidak memperkenankan diskriminatif atas sesama.Allah hanya membedakan manusia menurut takwanya. Sebagaimana firman Allah dalam QS. Al-Hujarat atar 13:

"Hai manusia, sesungguhnya Kami ciptakan kamu dari seorang laki-laki seorang perempuan dan menjadikan kamu berbangsa-bangsa dan bersuku-suku supaya kamu saling kenal-mengenal. Sesungguhnya orangyangpaling mulia diantara kamu di sisi Allah adalab orang yang paling taqwa diantara kamu.Sesungguhnya Allah Maha Mengetahui lagi Maha Mengenal."

Artinya, manusia hanya lebih tinggi daripada yang lain karena ketakwaannya kepada Allah, yaitu kemampuannya untuk melaksanakan kewajiban-kewajiban yang diperintahkan oleh Allah dan menjauhi larangan-larangan Allah. ${ }^{14}$ Demikian dengan hubungan bank dan nasabah bank tidak boleh menggunakan posisi kuatnya untuk menekan nasabah dengan hak dan kewajiban yang tidak seimbang.Bank harus memberikan kepedualian terhadap nasabah yang mempunyai posisi lemah dan tidak mempunyai kekuasaan.

Islam melindungi kaum yang lemah terhadap suatu ke-zalim-an. Zalimun atau zalimin artinya adalah orang yang aniaya (termasuk terhadap diri sendiri). Orang zalim adalah orang yang tidak menempatkan sesuatu pada tempatnya. Orang yang menghukum tidak berdasarkan hukum yang adil.Orang yang bertindak tidak sesuai dengan permainan yang telah dibuat atau diundangkan. Orang yang melanggar hak-hak asasi Tuhan dan juga melanggar hak-hak asasi manusia. ${ }^{15}$

Zalim dalam permasalahan ini termasuk pada transaksi yang menimbulkan ketidakadilan bagi para pihak lainnya karena meletakkan hak dan kewajiban tidak sebagaimana porsinya. Menurut Sutan Remi Sjahdeini, suatu transaksi yang zalim adalah suatu transaksi yang akadnya berat sebelah atau timpang. Akad yang berat sebelah bargaining position nya tidak setara. Satu pihak lebih banyak hanya menentukan apa yang menjadi hak-hak pihak yang mempunyai posisi kuat dengan kurang menentukan yang menjadi kewajiban-kewajibannya kepada pihak lainnya, 14 Sutan Remy Sjahdeini, Perbankan Syariab: Produk-produk dan Aspek-aspek Hukumnya (Jakarta: Kencana, 2015), h. 21.

15 Saifuddin Mujtaba, 73 Golongan Sesat dan Selamat (Surabaya: Pustaka Proggresif, 1992), h. 229. 
sebaliknya dalam akad tersebut lebih banyak mengatur kewajiban-kewajiban pihak lain yang posisinya lemah dan kurang menentukan apa hak-hak terhadap pihak lainnya. Kriteria ini sama dengan penyalahgunaan keadaan yang dilakukan bank terhadap nasabah. Selain, bargaining position tidak seimbang juga menimbulkan hak dan kewajiban yang timpang. Bank harus memperhatikan perlindungan yang seimbang terhadap kepentingan kedua belah pihak, baik untuk pihak bank maupun pihak nasabah. Tidak dibenarkan perjanjian atau akad perbankan syariah hanya menentukan hak-hak salah satu pihak. Penekanan oleh pihak yang lebih kuat kepada pihak yang lemah termasuk perbuatan zalim.

Zalim termasuk dari hal yang dilarang dalam akad muamalah. PBI No.10 /16/PBI/2008 tentang pelaksanaan Prinsip Syariah dalam kegiatan Penghimpunan Dana dan Penyaluran Dana serta Pelayanan Jasa Bank Syariah menjelaskan bahwa transaksi syariah harus terbebas atau tidak mengandung gharar, maisir, riba, zalim dan objek haram. Jadi, perjanjian dalam transaksi syariah yang mengandung unsur zalim termasuk hal yang dilarang dan tidak sesuai dengan prinsip syariah.

Zalim termasuk transaksi yang haram. Terdapat dua faktor yang menyebabkan transaksi perjanjian atau akad dilarang untuk dilakukan, yaitu:

1. Haram zatnya (objek transaksinya). Suatu transaksi dilarang karena objek (barang dan/atau jasa) yang ditransaksikan merupakan objek yang dilarang (haram) dalam hukum agama Islam. Seperti memperjualbeli kan alkohol, narkoba, organ manusia, dll.

2. Haram selain zatnya (cara bertransaksinya) terbagi menjadi 13,antara lain:

Maisir. Semua bentuk perpidahan harta ataupun barang dari satu pihak kepada pihak lain tanpa melalui jalur akad yang telah digariskan Syariah, namun perpindahan itu terjadi melalui permainan, seperti taruhan uang pada permainan kartu, pertandingan sepak bola, pacuan kuda, pacuan greyhound dan seumpamanya. Menurut bahasa maisir berarti gampang/mudah. Menurut istilah maisir berarti memperoleh keuntungan tanpa harus bekerja keras. Maisir sering dikenal dengan perjudian karena dalam praktik perjudian seseorang dapat memperoleh keuntungan dengan cara mudah. Dalam perjudian, seseorang dalam kondisi bisa untung atau bisa rugi.

Jenis Barang Ribawi. Para ahli fiqih Islam telah membahas masalah riba dan jenis barang ribawi dengan panjang lebar dalam kitab-kitab mereka. Dalam kesempatan ini akan disampaikan kesimpulan umum dari pendapat mereka yang intinya bahwa barang ribawi meliputi Emas dan perak, baik itu dalam bentuk uang maupun dalam bentuk lainnya. Bahan makanan pokok seperti beras, gandum, dan jagung serta bahan makanan tambahan seperti sayur-sayuran dan buah-buahan. 
Gharar/Taghrir. Sesuatu yang tidak jelas dan tidak dapat dijamin atau dipastikan kewujudannya secara matematis dan rasional baik itu menyangkut barang (goods), harga (price) ataupun waktu pembayaran uang/penyerahan barang (time of delivery). Taghrir dalam bahasa Arab disebut gharar, yang berarti akibat, bencana, bahaya, resiko, dan ketidakpastian. Dalam istilah fiqh muamalah, taghrir berarti melakukan sesuatu secara membabi buta tanpa pengetahuan yang mencukupi; atau mengambil resiko sendiri dari suatu perbuatan yang mengandung resiko tanpa mengetahui dengan persis akibatnya, atau memasuki kancah resiko tanpa memikirkan konsekuensinya. Gharar terbagi menjadi gharar kuantitas, gharar kualitas, gharar dalam harga, gharar menyangkut waktu penyerahan.

Riba. Al-Quran dan Sunnah dengan sharih telah menjelaskan keharaman riba dalam berbagai bentuknya; dan seberapun banyak riba tersebut dipungut. Riba secara bahasa bermakna ziyadah (tambahan). Dalam pengertian lain, secara linguistik riba juga berarti tumbuh dan membesar. Sedangkan menurut istilah teknis, riba berarti pengambilan tambahan dari harta pokok atau modal secara bathil. Ada beberapa pendapat dalam menjelaskan riba, namun secara umum terdapat benang merah yang menegaskan bahwa riba adalah pengambilan tambahan, baik dalam transaksi jual-beli maupun pinjam-meminjam secara bathil atau bertentangan dengan prinsip muamalat dalam Islam.

Bai' Al Mudtarr. Adalah jual beli dan pertukaran dimana salah satu pihak dalam keadaan sangat memerlukan (in the state of emergency) sehingga sangat mungkin terjadi eksploitasi oleh pihak yang kuat sehingga terjadi transaksi yang hanya menguntungkan sebelah pihak dan merugikan pihak lainnya.

Ikrah. Segala bentuk tekanan dan pemaksaan dari salah satu pihak untuk melakukan suatu akad tertentu sehingga menghapus komponen mutualfree consent. Jenis pemaksaan dapat berupa acaman fisik atau memanfaatkan keadaan seseorang yang sedang butuh atau the state of emergency. Imam Ibnu Taimiyah ra mengatakan bahwa dalam keadaan darurat (state of emergency) seseorang yang memilik stock barang yang dibutuhkan orang banyak harus diperintahkan untuk menjualnya dengan harga pasar, jika dia enggan melakukannya pihak berkuasa dapat memaksanya untuk melakukan hal tersebut demi menyelamatkan nyawa orang banyak. Paksaan yang dapat mendorong seseorang untuk melakukan sesuatu bukan berdasar pilihan bebasnya dapat menyebabkan batalnya akad. ${ }^{16}$

Ghabn. Adalah dimana si penjual memberikan tawaran harga diatas ratarata harga pasar (market price) tanpa disadari oleh pihak pembeli. Ghabn ada dua jenis yakni: Ghabn Qalil (Negligible) dan Ghabn Fahish (Excessive).

16 Abdul Jalil, “Tumpang Tindih Kewenangan dalam Penyelesaian Sengketa Perbankan Syariah”, Jurnal Konstitusi, Volume 10, Nomor 4, Desember 2013, h. 638. 
Bai'Najash. Adalah sebuah situasi di mana konsumen/pembeli menciptakan demand (permintaan) palsu, seolah-olah ada banyak permintaan terhadap suatu produk sehingga harga jual produk itu akan naik. Cara yang bisa ditempuh bermacam-macam, seperti menyebarkan isu, melakukan order pembelian, dan sebagainya. Ketika harga telah naik maka yang bersangkutan akan melakukan aksi ambil untung dengan melepas kembali barang yang sudah dibeli, sehingga akan mendapatkan keuntungan yang besar. Sebagai contoh: ini sangat rentan terjadi ketika pelelangan suatu barang. Biasanya yang mengadakan pelelangan bekerja sama dengan beberapa peserta pelelangan dimana mereka bertugas untuk berpura-pura melakukan penawaran terhadap barangyang dilelang, dengan kata lain untuk menaikkan harga barang yang dilelang tersebut. Ihtikar Adalah menumpuknumpuk barang ataupun jasa yang diperlukan masyarakat dan kemudian si pelaku mengeluarkannya sedikit-sedikit dengan harga jual yang lebih mahal dari harga biasanya dengan tujuan untuk mendapatkan keuntungan lebih cepat dan banyak. Para ulama tidak membatasi jenis barang dan jasa yang ditumpuk tersebut asalkan itu termasuk dalam kebutuhan essential, maka Ihtikar adalah dilarang. Rasulullah saw bersabda: "Barangsiapa yang menimbun (barang \& jasa kebutuhan pokok) maka telah melakukan suatu kesalahan."

Ghish. Menyembunyikan fakta-fakta yang seharusnya diketahui oleh pihak yang terkait dalam akad sehingga mereka dapat melakukan kehati-hatian (prudent) dalam melindungi kepentingannya sebelum terjadi transaksi yang mengikat. Dalam Common Law akad seperti ini dikenal dengan sebutan Akad Uberrime Fidae Contract dimana semua jenis informasi yang seharusnya diketahui oleh pelanggan sama sekali tidak boleh disembunyikan. Jika ada salah satu informasi berkenaan dengan subject matter akad tidak disampaikan, maka pihak pembeli dapat memilih opsi membatalkan transaksi tersebut.

Tadlis. Adalah tindakan seorang peniaga yang sengaja mencampur barang yang berkualitas baik dengan barang yang sama berkualitas buruk demi untuk memberatkan timbangan dan mendapat keuntungan lebih banyak Tindakan "oplos" yang hari ini banyak dilakukan termasuk kedalam kategori tindakan tadlis ini. Rasullah saw sering melakukan 'inspeksi mendadak' ke pasar-pasar untuk memastikan kejujuran para pelaku pasar dan menghindari konsumen dari kerugian.

Talaqqil Jalab Atau Talaqqi Rukban. Yang dimaksud dengan jalab adalah barang yang diimpor dari tempat lain. Sedangkan rukban yang dimaksud adalah pedagang dengan menaiki tunggangan. Adapun yang dimaksud talaqqiljalab atau talaqqi rukban adalah sebagian pedagang menyongsong kedatangan barang dari 
tempat lain dari orang yang ingin berjualan di negerinya, lalu ia menawarkan harga yang lebih rendah atau jauh dari harga di pasar sehingga barang para pedagang luar itu dibeli sebelum masuk ke pasar dan sebelum mereka mengetahui harga sebenarnya.

Jual Beli Hadir Lil Baad, Menjadi Calo Untuk Orang Desa (Pedalaman). Yang dimaksud bai' hadir lil baad adalah orang kota yang menjadi calo untuk orang pedalaman atau bisa jadi bagi sesama orang kota. Calo ini mengatakan, "Engkau tidak perlu menjual barang-barangmu sendiri. Biarkan saya saja yang jualkan barang-barangmu, nanti engkau akan mendapatkan harga yang lebih tinggi”.

Risywah (Suap). Risywah menurut bahasa berarti: "pemberian yang diberikan seseorang kepada hakim atau lainnya untuk memenangkan perkaranya dengan cara yang tidak dibenarkan atau untuk mendapatkan sesuatu yang sesuai dengan kehendaknya." (al-Misbah al-Munir/al Fayumi, al-Muhalla/Ibnu Hazm). Atau "pemberian yang diberikan kepada seseorang agar mendapatkan kepentingan tertentu” (lisanul Arab, dan mu'jam wasith).

Penyalahgunaan keadaan (misbruik van omstandigheiden atau undue influence) dalam transaksi syariah termasuk Ikrah.Secara bahasa ikrah artinya memaksa. Sedangkan secara terminologis, para ahli hukum Islam berbeda pendapat tentang pengertian ikrah. Abdul Qadir Audah memberikan pengertian ikrah sebagai "Suatu perbuatan yang ditimbulkan dari pemaksa dan menimbulkan pada diri orang yang dipaksa suatu keadaan yang mendorong dirinya untuk mengerjakan perbuatan yang dituntut (oleh pemaksa) darinya". Pendapat lain dikemukakan oleh Muhammad Abu Zahrah bahwa ikrah adalah menyuruh seseorang melakukan sesuatu yang di benci nya. Apabila kita perhatikan dari beberapa pengertian ikrah, maka $i k r a h$ berarti ancaman dari orang yang memaksa terhadap orang yang dipaksa yang membuatnya harus melakukan suatu perbuatan yang dipaksakan padanya. Paksaan biasanya disertai dengan ancaman dapat berupa penyiksaan, ancaman pembunuhan, pemukulan, dan lain-lain.

Dengan demikian, penyalahgunaan keadaan (misbruik van omstandigheiden atau undue influence) dapat dikategorikan sebagai transaksi yang dilarang dalam perjanjian syariah. Rumusannya perjanjian syariah atau akad tersebut hukumnya halal atau haram dapat dilihat pada gambar berikut ini: 


\begin{tabular}{c|c|c|}
\multicolumn{1}{c}{} & \multicolumn{2}{c}{ Gambar 1: Rumus Perjanjian syariah } \\
\cline { 2 - 3 } Objek Halal & Cara Halal & Cara Haram \\
\cline { 2 - 3 } Objek Haram & A & B \\
& Transaksi Halal & Transaksi Haram \\
\cline { 2 - 3 } & $\begin{array}{c}\text { C } \\
\text { Transaksi } \\
\text { Haram }\end{array}$ & Transaksi Haram \\
\hline
\end{tabular}

Transaksi penyalahgunaan keadaan (misbruik van omstandigheiden atau undue influence) termasuk kuadran B karena meskipun obyek transaksinya halal, namun cara bertransaksinya adalah haram, maka hukum dari transaksi tersebut menjadi haram. Memaksa nasabah untuk menantangani perjanjian tanpa diberikan kesempatan untuk mengemukakan pendapat karena nasabah merupakan pihak yang mempunyai posisi lemah termasuk pada cara yang haram.

Apabila terdapat perjanjian syariah yang mengandung unsur penyalahgunaan keadaan (misbruik van omstandigheiden atau undue influence) maka perjanjian tersebut ikrah karena mengandung unsur zalim. Akibat hukum dari perjanian yang mengandung penyalahgunaan keadaan (misbruik van omstandigheiden atau undue influence), yaitu perjanjian tersebut menjadi batal demi hukum.

\section{Simpulan}

Berdasarkan kajian ada pembahasan maka dapat dibuat kesimpulan:

1. Konsep penyalahgunaan keadaan (misbruik van omstandigheden) dalam perjanjian termasuk dalam perjanjian yang cacat kehendak. Penyalahgunaan keadaan (misbruik van omstandigheden) dalam perjanjian timbul karena terdapat salah satu pihak yang mempunyai posisi kuat untuk menekan bahkan mengancam terhadap pihak yang mempunyai posisi lebih lemah. Bargaining position tidak seimbang antara satu pihak dengan pihak yang lain. Penyebabnya adalah karena pihak yang punya posisi lemah tidak diberikan kebebasan untuk memberikan pendapatnya atas isi perjanjian. Hingga saat ini belum terdapat peraturan perUndang-Undangan di Indonesia yang secara limitatif menyebutkan kriteria penyalahgunaan keadaan. Namun, telah ada yurisprudensi atas kasus yang mengandung Penyalahgunaan keadaan (misbruik van omstandigheden).

2. Perjanjian syariah yang mengandung unsur penyalahgunaan keadaan (misbruik van omstandigheiden atau undue influence) termasuk pada perjanjian yang dilarang, yang disebut dengan ikrah. Ikrah adalah pemaksaan. Ikrah dalam perjanjian syariah berarti ada pemaksaan dari pemilik posisi kuat terhadap pihak yang 
mmepunyai posisi lebih lemah. Berbuat Ikrah berarti berbuat zalim. Akibat hukum dari perjanian yang mengandung penyalahgunaan keadaan (misbruik van omstandigheiden atau undue influence), yaitu perjanjian tersebut menjadi batal demi hukum.

\section{Daftar Pustaka}

\section{Buku}

Al-Busti, Abu Hatim Muhammad ibn Hibban al-Tamimi al-Darimi. Shabih Ibn Hibban. Beirut: Mu'assasah ar- Raisalah, 1414/1993.

Budiono, Herlien. Ajaran Umum Hukum Perjanjian Dan Penerapannya Di Bidang Kenotariatan. Jakarta: Citra Aditya Bakti, 2010.

Dewi, Gemala. Hukum Perikatan Islam di Indonesia, cet. Ke-2. Jakarta: Kencana, 2006.

Hernoko, Agus Yudha. Hukum Perjanjian Asas Proposionalitas Dalam Kontrak Komersial. Surabaya: Kencana Prenada Media Grup, 2013.

J.Satrio. Hukum Perikatan, Perikatan pada Umumnya. Bandung: Alumni, 1999.

Khairandy, Ridwan. Hukum Kontrak Indonesia Dalam Perspektif Perbandingan (Bagian Pertama). Yogyakarta: FH UII Press, 2013.

Mujtaba, Saifuddin. 73 Golongan Sesat dan Selamat. Surabaya: Pustaka Proggresif, 1992.

Sjahdeini, Sutan Remy. Perbankan Syariah: Produk-produk dan Aspek-aspek Hukumnya. Jakarta: Kencana, 2015.

Subekti. Aneka Perjanjian. Bandung: Citra Aditya Bakti, 1995.

Triana, Yenny. Pemahaman Iktikad Baik Dan Penyalahounaan Keadaan Dalam Kontrak. Fakultas Hukum Universitas Lancang Kuning.

\section{Artikel}

Arifin, Muhammad. Penyalahgunaan Keadaan Sebagai Faktor Pembatas Kebebasan Berkontrak. Jurnal Ilmu Hukum, Vol. 14, No. 2, September 2011.

Jalil, Abdul . "Tumpang Tindih Kewenangan dalam Penyelesaian Sengketa Perbankan Syariah", Jurnal Konstitusi, Volume 10, Nomor 4, Desember 2013. 
Khairandy,Ridwan. Kemerosotan Supremasi Asas Kebebasan Berkontrak. Makalah disampaikan pada Departermen Hukum Keperdataan Fakultas Hukum Universitas Islam Indonesia Yogyakarta pada tanggal 16 Agustus 2000.

Paparang, Fatmah. "Misbruik Van Omstandigheden Dalam Perkembangan Hukum Kontrak”, Jurnal Hukum Unsrat Vol.22/No.6/Juli/2016.

Simanjuntak, Ricardo. Akibat Dan Tindakan-Tindakan Hukum Terbadap Pencantuman Klausula Baku Dalam Polis Asuransi Yang Bertentangan Dengan Pasal 18 Undang-Undang No.8/1999 Tentang Perlindungan Konsumen. Jurnal Hukum Bisnis, Vol. 22, No. 2, Tahun 2003. 